\title{
ПРАВОВЕ РЕГУЛЮВАННЯ КОНСТАТАЦIї СМЕРТІ ГОЛОВНОГО МОЗКУ
}

\author{
БОГОМАЗОВА Ірина Олександрівна - кандидат юридичних наук, доцент \\ кафедри медичного права, факультет післядипломної освіти Львівського \\ національного медичного університету імені Данила Галицького
}

DOI 10.32782/EP.2020.3.21

Тест апноетической оксигенации в соответствии с Диагностическими критериями смерти человека представляет собой завершительную процедуру констатации смерти человека. Данная прочедура несовместима с методами лечения больных в коме, поскольку связана с гипотонией, что Фбактически означает изменение отношения, в результате которой человек считается уже не пациентом, а умершим. В статье анализируются альтернативъ законодательного регулирования соотношения ответственности иленов семьи и лечебного учреждения при проведении теста апноетической оксигенации, и роль конструкциии презумпиии согласия для обеспечения сбалансированного и достойного с точки зрения психологии отношение $\kappa$ пациенту и иленов его семьи. Для национального же законодателя на даннъй момент актуальнълм остается приведение диагностических критериев смерти человека в соответствии с частью 1 статьи 43 Основ законодательства об охране здоровья в части введения права членов семьи запретить проведение Теста.

Ключевъге слова: смерть головного мозга, тест апноетической оксигенации, отключение от аппарата искусственной вентиляции легких, права пациента.

Постановка проблеми

Констатація смерті головного мозку становить собою одну з найбільш обговорюваних проблем біоетики та юриспруденції протягом багатьох років. Між тим, хоча дійти згоди 3 цього питання в масштабах суспільства навряд чи можливо, законодавство й судова практика мали дійти певного висновку стосовно найбільш справедливого балансу інтересів у правовідношенні між лікувальним закладом і членами сім'ї пацієнта, щодо якого проводиться констатація смерті головного мозку.

Тест апноетичної оксигенації (Apnoe Testing $\square$ ) або роз'єднувальний тест (далі Тест) згідно із Діагностичними критеріями смерті людини [1] становить завершальну складову процедури констатації моменту смерті людини. Цим положенням переважно і можна пояснити суспільний резонанс, що супроводжує обговорення. Всередині цих дискусій перебуває питання про те, чи потрібна для проведення Тесту згода членів сім'ї, адже застосування цього Тесту без такої згоди охоплюється змістом ст. 2 Конвенції про захист прав людини та основоположних свобод (далі - Конвенції), а відтак може кваліфікуватись як втручання у право людини на життя.

Неврологічне діагностування смерті

Процедура діагностування смерті людини передбачає встановлення: 1) повної та стійкої відсутності свідомості (коми);2) атонії всіх груп м'язів; 3) відсутності реакції на великі больові подразнення в зоні тригемінальних точок та будь-яких інших рефлексів, що замикаються вище шийного відділу спинного мозку; 4) відсутність реакції зіниць на пряме яскраве світло (якщо відомо, що жодні препарати, які розши- 


\section{Цивільне, підприсмницьке, господарське та трудове право}

рюють зіниці, не застосовувались); 5) очей ляльки (нерухомого положення очних яблук); 6) відсутності корнеальних рефлексів; 7) відсутності окулоцефалічних рефлексів ; 8) відсутності окуловестибулярних рефлексів ${ }^{1 ;}$ відсутності фарингіальних та трахеальних рефлексів, які визначаються шляхом руху ендотрахеальної трубки в трахеї та верхніх дихальних шляхах, а також при просуванні катетера в бронхах для аспірації секрету; 10) відсутності самостійного дихання. Визначати відсутність дихання не дозволяється простим відключенням від апарата штучної вентиляції легенів (далі - ШВ $\mathcal{\lambda}$ ), оскільки гіпоксія, яка при цьому розвивається, шкідливо впливає на організм, передусім на мозок і серце $\mathrm{e}^{2}$.

Після отримання результатів дослідження на відповідність зазначеним критеріям, переходять до проведення роз'єднувального тесту. Останній, у свою чергу, складається з трьох етапів: на першому етапі для моніторингу газового складу крові: парціального тиску кисню та вуглекислого газу (далі - РаСО2) - повинна бути канюльована одна з артерій кінцівки; на другому етапі перед роз'єднанням респіратора необхідно протягом 10 - 15 хвилин проводити ШВ $\Lambda$ у режимі, що забезпечує усунення гіпоксемії та гіперкапнії, - FiO2 = 1,0 (тобто $100 \%$ кисень) 3 підібраною Vtet (хвилинна вентиляція) в обсязі 8 - 10 ^/хв та оптимальним позитивним тис-

\footnotetext{
${ }^{1}$ Хоч назва каже, що цей нормативний документ присвячено саме критеріям смерті, все ж більш точно можна сказати, що його присвячено процедурі його проведення та відповідним обов'язкам лікарів. ${ }^{2}$ Для дослідження окуловестибулярних рефлексів проводиться двостороння калорична проба. Перед іiі проведенням необхідно переконатись у відсутності перфорації барабанних перетинок. Голову хворого піднімають на $30^{\circ}$ вище від горизонтального рівня. У зовнішній слуховий прохід уводять катетер малих розмірів, здійснюють помірне зрошування зовнішнього слухового проходу холодною водою $(\mathrm{t}$ $=20^{\circ} \mathrm{C}, 100$ мл) протягом 10 сек. При збереженій функції стовбура головного мозку через 20 - 25 сек. з'являється ністагм або відбувається відхилення ока у бік повільного компонента ністагму. Відсутність ністагму або відхилення очних яблук при калоричній пробі, що виконана з обох боків, свідчить про відсутність окуловестибулярних рефлексів;
}

ком у кінці видоху (РЕЕР) 5 - 10 см вод. ст.; на третьому етапі, а саме після виконання першого та другого етапів, апарат шВ $\mathcal{A}$ відключають і в ендотрахеальну та трахеостомічну трубку подають вологий $100 \%$ кисень зі швидкістю 8 - 10 ^ на хвилину. Водночас відбувається накопичення ендогенної вуглекислоти, що контролюється шляхом забору проб артеріальної крові. При цьому, накопичення вуглекислоти 6 надзвичайно шкідливим, хоч i, певна річ, не може зашкодити мертвій людині.

Діагностичні критерії смерті людини не передбачають необхідності отримати згоду ід членів сім’ї хворого на проведення такого Тесту. Однак згідно з частиною 1 статті 43 Закону України «Основи законодавства про охорону здоров'я» (далі Основ законодавства) згода пацієнта необхідна для застосування методів не лише лікування та профілактики, але і діагностики. Щодо пацієнтів віком до 14 років, а також пацієнтів, визнаних в установленому законом порядку недієздатними, медичне втручання здійснюється за згодою їх законних представників. Таким иином, ми тут зустрічаємось із подвійною колізією - загальної та спеціальноӥ норми, й водночас норм вищого та нижчого джерел права за юридичною силою.

Національне законодавство може передбачати проведення Тесту:

- $\quad$ аа дійсною згодою представників пацієнта [1, с. 267];

- без такої згоди в разі наявності спростовної презумпції згоди [2, с. 66];

- $\quad$ за розпорядженням лікаря безвідносно згоди представників пацієнта, [3, с. 46].

Різноманіття способів вирішення питання про згоду на проведення Тесту можна спостерігати у рішеннях вищих судів Сполучених Штатів [4-10], де поки з умовним рахунком 4:2 виграють прихильники надання згоди. Втім, такий стан справ сам по собі не є доказом моральної невідповідності процедури проведення Тесту без отримання згоди сім’ї. Тому варто стисло проаналізувати аргументи, котрі становлять фундамент двох протилежних точок зору на питання. 
Так, прихильники згоди на проведення Тесту спираються як на підстави на те, що діагноз може бути помилковим і недостовірним. Звучать також аргументи релігійного характеру. Обгрунтовують навіть те, що смерть головного мозку може бути не патологічним процесом.

Цікавою є практика штату Нью-Джерсі, де його громадянам надається право відмовитись від згоди на проведення Тесту за релігійними переконаннями ${ }^{3}$ [12], що може, на нашу думку, розглядатись як дискримінація тих, хто не має релігійних переконань. Втім, як видається, така норма не вирішує проблему роз'єднувального тесту, ба навпаки, ускладнює. Так, наявність релігійних переконань є ознакою для надання дискримінаційного пріоритету у користуванні немайновими правами. Можна припустити, що люди, які не сповідують жодних релігійних поглядів, у світлі такого законодавства вимушені змушувати іти на поступки власну совість, видаючи себе за релігійних, аби тільки запобігти відключенню близького родича від апарату ШВ $\lambda$. Отже, відмова від згоди на проведення Тесту за релігійними переконаннями, вочевидь, передбачає вирішення конфлікту інтересів на користь однієї зі сторін без їі справедливої переваги.

Що стосується аргументів 3 боку тих, хто заперечує потребу в отриманні згоди, то вони зазначають, що проведення Тесту не можна розглядати як лікування, а відтак згода родичів вимагатись не повинна. Однак, як нам видається, це дуже слабкий аргумент, оскільки спричинення шкоди здоров'ю пацієнта роз'єднувальним тестом не може не породити природного права родичів заперечувати проти його проведення.

\footnotetext{
3 Контроль газів крові здійснюється: до початку тесту в умовах ШВ $\Lambda$; через $10-15$ хвилин після початку ШВЛ 100 \% киснем, одразу після відключення від ШВ $\curlywedge$; далі через кожні 10 хвилин, доки PaCO2 не досягне 60 мм рт. ст. Якщо при цих та (або) вищих значеннях спонтанні дихальні рухи не відновлюються, роз'єднувальний тест засвідчує відсутність функцій дихального центру стовбура головного мозку. При появі мінімальних дихальних рухів, незважаючи на рівень $\mathrm{PaCO} 2$, ШВ $\Lambda$ відразу поновлюється.
}

Крім того, стверджують, що в умовах, коли ШВЛ може надаватись обмеженому колу людей, або з огляду на неспроможність забезпечити оплату послуг 3 його забезпечення, право проводити Тест має бути надане лікарям без котр-сигнації 3 боку членів сім’і. Це міркування є цілком справедливим. Насправді дискусія про необхідність проведення Тесту впирається в питання про обмеженість ресурсів для штучного підтримання життя, відповідно, не могло б бути проблемою за відсутності такого обмеження.

Інтерес у проведенні Тесту без отримання згоди з боку родичів мають передусім заклади охорони здоров'я, які зацікавлені в ефективному використанні власних ресурсів. Природно, що міркування врятувати життя для адміністрації переважає міркування про штучне підтримання ілюзії життя.

Aле моральний бік питання може зовсім інакше уявлятись для родичів, котрі цілком природно можуть вирішити боротись за життя пацієнта до кінця й будуть сприймати проведення Тесту як процедуру, аналогічну до вбивства. Навряд чи є можливість знайти компромісне вирішення питання, котре буде однаково добре задовольняти інтереси обох сторін. I саме в цьому контексті важливо розрізняти ситуацію з обмеженими і необмеженими ресурсами. Якщо ресурси є необмеженими, що не так просто собі уявити, згода членів сім’і на проведення Тесту має бути обов'язковою, тоді як за умови обмежених ресурсів необхідним 6 погоджувальний порядок.

Згідно 3 Правилами встановлення i фіксації смерті штату Невада, згода на проведення Тесту не вимагається [13], однак члени сім’ї протягом двох діб мають право заперечити проти його проведення i від'єднання пацієнта від апарату ШВ $\mathcal{~}$ Таким чином, юридична конструкція проведення Тесту за правилами штату створює свою систему відносин між членами сім'ї пацієнта, з одного боку, та медичним закладом, 3 іншого. Психологічно простіше не заперечувати проти проведення роз'єднувального тесту, ніж ухвалити власне вольове рішення й надати на це згоду. 


\section{Цивільне, підприсмницьке, господарське та трудове право}

\section{АНОТАЦІЯ}

Тест апноетичної оксигенациї згідно із Діагностичними критеріями смерті людини становить завершальну складову процедури констатаиї моменту смерті людини. Означена прочедура не сумісна з методами лікування хворих у комі, оскільки пов'язана з гіпотонією $i$ фактично $i$ означає зміну ставлення, у результаті чого людина вважається вже не пацієнтом(-кою), а померлим (-ою). У статті аналізуються альтернативи законодавчого регулювання співвідношення відповідальності членів сім'ї та закладу охорони здоров'я при проведенні тесту апноетичної оксигенацї, а також роль конструкиій презумпиіӥ згоди для забезпечення збалансованого $i$ гідного з точки зору психологї ставлення до пацієнта та членів його сім'ї. Для наиіонального ж законодавия на ией момент актуальним залишається приведення Діагностичних критерї̈ смерті людини у відповідність з частиною 1 статті 43 Основ законодавства про охорону здоров'я в частині введення права членів сім'ї заборонити проведення Тесту.

Ключові слова: смерть головного мозку, тест апноетичної оксигеначій, відключення від апарата штучної вентиляиї легень, права nаиієнта.

Це зважений спосіб розподілу відповідальності між суб'єктами прововідношення, котрий породжуватиме найменшу кількість судових спорів.

\section{Висновки}

Важливо відзначити, що проведення Тесту передбачає проведення дій, що прямо порушують методи лікування хворих у комі, а саме, гіпотонія не повинна допускатись у жодному випадку, як така, що може спричинити тяжкі наслідки (дислокація чи внутрішня грижа мозку) $[11$, с. 9]. Отже, як виявляється, оминути згоду сім'ї з міркувань моралі і моральних міркувань неможливо.

Однак, вважаємо, що складне питання в дискусії може прозвучати в майбутньому, якщо діагностувати наявність реакції мозку зможуть в інший спосіб, котрий не завдає шкоди пацієнтові. Тоді доведеться вирішити, чи має взагалі право на існуван- ня неврологічна процедура встановлення смерті (головного мозку), чи справа насправді не в ній, а в тому, що аморальним $є$ саме по собі від'єднання від апарату ШВ $\lambda$.

Для нашого ж законодавця на цей момент актуальним залишається приведення Діагностичних критеріїв смерті людини у відповідність з частиною 1 статті 43 Закону України «Основи законодавства про охорону здоров'я» в частині введення права членів сім'ї заборонити проведення Тесту.

\section{Лiтература}

1. Діагностичні критерії смерті людини. Наказ Міністерства охорони здоров'я України від 23.09.2013 № 821.

2. Pope, T. M. Brain death forsaken: Growing conflict and new legal challenges // Journal of Legal Medicine 37(3-4), 2017, Pp. 265-324.

3. Pope, T. Brain death and the law: Hard cases and legal challenges // Hastings Center Report 48(Suppl 4), 2018, Pp .46-68

4. Brain Death and the Law: Hard Cases and Legal Challenges // The Hastings Center Report, 48, Pp 46-48

5. In Re Allen Callaway, (2016) DG16-08, Montana Ninth Judicial District Pondera County (Sept. 2016) : [URL: http:// thaddeuspope.com/images/Order_Denying_ SVH_Motion_23sept2016.pdf]

6. Brett and Yvonne Shively v. Wesley Medical Center, 2006 WL 2922599 (Kan. App.) : [URL: http://www.thaddeuspope.com/ images/Brett_Shively_brief.pdf]

7. In Re Miranda Grace Lawson CL162358, City of Richmond Cir. Ct. VA. (2016) : [URL: http://www.thaddeuspope.com/images/ Petition_for_Appeal,_Lawson_v_VCU_09-1216_.pdf]

8. In Re Guardianship of Hailu, 361 P.3d 524 (Nev. 2015) : [URL: https://www.leagle. com/decision/innvco20151208291]

9. Veatch R.M. Controversies in defining death: a case for choice. Theor Med Bioeth 40, 381-401 (2019).

10. In Re Alex Pierce v. Loma Linda University Medical Center, Superior Court of California for the County of San Bernardino Case No. CIV.DS-1608931 (2016) : [URL: http://www.thaddeuspope.com/images/ 
Pierce_v_Loma_Linda_petition_June_2016. pdf]

11. California In Re Stinson v. Children's Hospital of Los Angeles, No. BS164387 (Los Angeles Sup. Ct.) (CA) 2016 : [URL: http:// www.thaddeuspope.com/images/Stinson response_to_Hosp_App.pdf]

12. Ivor Berkowitz \& Jeremy R. Garrett. Legal and Ethical Considerations for Requiring Consent for Apnea Testing in Brain Death Determination, The American Journal of Bioethics, 20:6, 2020, Pp. 4-16.

13. New Jersey Declaration of Death Act : [URL: http://www.braindeath.org/law/ newjersey.html]

14. Assembly Bill No. 424, Nevada, 2017, $79^{\text {th }}$ session: [URL: https://www.leg.state. nv.us/App/NELIS/REL//79th2017/Bill/5570/ $\underline{\text { Text] }}$
The Apnoe testing, according to the Diagnostic Criteria of Human Death, is the final procedure for determining the moment of human death. This procedure is incompatible with the treatment of patients in coma, because it is associated with hypotension and in fact means a change in attitude to the patient. The person, consequently, is not considered a patient, but dead.

The diagnostic criteria for a person's death do not require the consent of the patient's family members to perform such a test under the Ukrainian legislation. However, according to Part 1 of Article 43 of the Law of Ukraine "Fundamentals of Health Care Legislation", the patient's consent is required for the application of methods not only treatment and prevention, but also diagnosis. In the case of patients under the age of 14, as well as patients who have been declared incapacitated in accordance with the procedure established by law, medical intervention is carried out with the consent of their legal representatives. Thus, here we encounter a double conflict - the general and special rules, and at the same time the rules of higher and lower sources of law by legal force.

A variety of ways to resolve the issue of consent to the Test can be observed in the decisions of the highest courts of the United States [4-10], where so far with a conditional score of 4: 2 supporters of consent take a win. However, this state of affairs is not in itself evidence of a moral inconsistency in the procedure of conducting the Test without the consent of the family. Therefore, it is necessary to assess the arguments that form the grounds of two opposing views on the issue.

Proponents of consent to the test advance the argument that the diagnosis may be erroneous and inaccurate. There are also arguments of a religious nature. It is even substantiated that brain death may not be a pathological process.

The article analyzes the alternatives of legislative regulation of the legal relationship between family and medical institutions in the Apnea testing, and the role of the construction of the presumption of consent to ensure a due attitude to the patient and his family. At the moment, it is important for the national legislator to bring the Diagnostic Criteria of Human Death in accordance with the Fundamentals of Health Care Legislation in terms of introducing the right of family members to prohibit the testing.

Key words: brain death, apnea testing, disconnection from the ventilator, the rights of the patient. 